\title{
INFLUENCE OF WATER DEFICIT ON IRON AND ZINC UPTAKE BY Matricaria chamomilla $\mathbf{L}$.
}

\author{
Alireza Pirzad $^{1 *}$, Reza Darvishzadeh ${ }^{1}$, Iraj Bernousi $^{1}$, Abbas Hassani² $^{2}$, and Nuray Sivritepe ${ }^{3}$
}

Iron and zinc deficiency are a yield-limiting factor with major implications for field crop production in many agricultural regions of the world; this production is essential source of Fe and $\mathrm{Zn}$ in human and animal diets. Two experiments were conducted under greenhouse conditions to evaluate Fe and $\mathrm{Zn}$ uptake by German chamomile (Matricaria chamomilla L.) grown under several drought conditions. Treatments were arranged in four irrigation regimes $(95 \%, 80 \%, 65 \%$, and $50 \%$ field capacity) and six irrigation disruptions (stem formation, flower onset, full bloom, first harvest, second harvest, and control without disruption) based on a randomized complete block design with five and four replicates in experiments 1 and 2, respectively. In Experiment 1, the irrigation regimes had no significant effect on Fe and Zn uptake by German chamomile, which reached total means of Fe (39.68 mg kg-1) and Zn (29.15 mg kg-1). In Experiment 2, the highest amount of $\mathrm{Fe}\left(39.0 \mathrm{mg} \mathrm{kg}^{-1}\right)$ was obtained from irrigation disruption at first harvest; this is similar to the results of irrigation

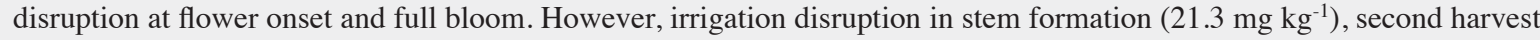
$\left(12.95 \mathrm{mg} \mathrm{kg}^{-1}\right)$, and the control $\left(7.79 \mathrm{mg} \mathrm{kg}^{-1}\right)$ had a decreasing trend of Fe uptake. The maximum value of $\mathrm{Zn}(40.0 \mathrm{mg}$ $\mathrm{kg}^{-1}$ ) occurred at irrigation disruption at the full bloom stage, which was also similar to irrigation disruption at flower onset and stem formation. However, later irrigation disruptions at the first and second harvest stages caused lower amounts of $\mathrm{Zn}$ uptake by chamomile. Therefore, the lowest $\mathrm{Zn}$ values were obtained from irrigation disruption at second harvest $(5.0 \mathrm{mg}$ $\mathrm{kg}^{-1}$ ) and the control $\left(5.5 \mathrm{mg} \mathrm{kg}^{-1}\right)$. Regressions between both Fe or $\mathrm{Zn}$ uptake and irrigation showed a binomial function.

Key words: Irrigation, Fe, Matricaria chamomilla, micronutrients, $\mathrm{Zn}$.

$\mathrm{H}$ eavy metals are considered as one of the main sources of environmental pollution. In biological and environmental studies, metals are classified in two categories: essential metals, such as $\mathrm{Fe}$ and $\mathrm{Zn}$; and nonessential or toxic metals, such as $\mathrm{Pb}$ and $\mathrm{Cd}$. Essential metals can also produce toxic effects when metal intake concentrations is high (Angelova et al., 2004). Iron is one of the most important micronutrients in the human diet and functions as a component of a number of proteins, including enzymes and hemoglobin (Institute of Medicine, Food and Nutrition Board, 2001). Plants are essential sources of $\mathrm{Fe}$ in human and animal diets and the Fe concentration in plants is often not enough to meet the daily dietary recommendations. Iron deficiency is a yield-limiting factor with major implications for field crop production in many agricultural regions of the world (Barton and Abadía, 2006). Krouma et al. (2003)

${ }^{1}$ Urmia University, Faculty of Agriculture, Department of Agronomy and Plant Breeding, Urmia 5715944931, Iran.

*Corresponding author (a.pirzad@urmia.ac.ir; alirezapirzad@yahoo. com).

${ }^{2}$ Urmia University, Faculty of Agriculture, Department of Horticulture, Urmia, Iran.

${ }^{3}$ Uludag University, Faculty of Agriculture, Department of Horticulture, Bursa 16059, Turkey.

Received: 24 August 2011.

Accepted: 25 May 2012. found differences in Fe reduction among five cultivars of common bean related to hydroponically induced Fe chlorosis, but no field chlorosis relationships were established in their study. An excessive Fe concentration causes vomiting, diarrhea, and also damages the intestine (Haider et al., 2004). Zinc is one of the most important trace elements in the body for many biological functions; it is required as a catalytic component for more than 200 enzymes and as a structural constituent of many proteins, hormones, neuropeptides, hormone receptors, and probably polynucleotides (Fabris and Mocchegiani, 1995). However, $\mathrm{Zn}$ is one of the essential micronutrients required for plant growth. It is an integral component or activator of a number of enzymes that represent almost all plant enzymatic groups. High soil Zn concentrations, a frequent consequence of anthropogenic activities, adversely affect plant life processes and can result in decreased biomass production and deteriorated quality of production (Vysloužilová et al., 2003).

Herbal or medicinal plant products in various forms have been available for hundreds of years to treat diseases in both Eastern and Western cultures. Plants are a rich source of secondary metabolites with medicinal and aromatic properties (Gómez-Galera et al., 2007). The world market for herbal medicines, including herbal products and raw materials, is currently growing at an annual rate of $5 \%$ to $15 \%$. This indicates a possible 
growing demand for plant-derived drugs in the upcoming years (Kumar and Gupta, 2008).

From the medical point of view, the most important plant constituents are the pharmacologically active compounds, including flavonoids, alkaloids, tannins, glycosides, sugars, and organic acids. However, medicinal plants contain considerable amounts of mineral constituents, and the presence of essential elements is a prerequisite for correct plant growth and development (Weber and Konieczyński, 2003).

There are already publications dealing with total element concentrations in medicinal plants, but only a few investigations deal with more detailed information on the forms of these elements, for example, availability of metals by using different extractants, or correlation of extracted metals with total amounts of organic substances (Zimna and Piekos, 1988; Szentmihalyi and Then, 2000).

Water availability is one of the most limiting factors in crop production and productivity. Over the past decade, the increased use of irrigation water and the concern over groundwater resources has brought about awareness to efficiently use water resources (Chai et al., 2005; Molassiotis et al., 2006). In dryland cropping systems, improving water use efficiency is an important goal for crop management and improvement. Maximizing available soil moisture and improving the crop's ability to sustain growth during water deficit periods will contribute to improved productivity and water use efficiency. By reducing root growth, zinc deficiency can limit the crop's ability to use soil moisture reserves (Nable and Webb, 1993), but the effect of $\mathrm{Zn}$ nutrition on the water stress response and plant water relationships has received little attention (Khan et al., 2004). Molassiotis et al. (2006) have reported $\mathrm{Fe}$ decrease in response to water stress. However, water deficit did not significantly influence $\mathrm{Zn}$ content in cherry rootstock Gisela (Sivritepe et al., 2008). The content of $\mathrm{Fe}$ and $\mathrm{Zn}$ in leaf tissue of Chlorophytum borivilianum was increased by both water deficit and waterlogging stresses. On the other hand, an increase in Fe content was observed in tuber tissue under both kinds of stresses (Nikam and Chavan, 2009).

We currently have little information on $\mathrm{Fe}$ and $\mathrm{Zn}$ uptake by chamomile plants under different water stress conditions. Therefore, we assessed changes of these metals in chamomile leaves under water deficit conditions.

\section{MATERIALS AND METHODS}

Seeds of Matricaria chamomilla L. tetraploid var. Bodegold, a chamazulene-high mixed type with a high bisabolol content obtained in Germany were used in the present study. Seeds were sown in $10 \mathrm{~L}$ pots filled with soil. The soil texture was clay-loam ( $28 \%$ silt, $33 \%$ clay, and $40 \%$ sand) with $22.5 \%$ field capacity, $1.54 \mathrm{~g} \mathrm{~cm}^{-3}$ soil density, $1.98 \%$ organic matter, and $\mathrm{pH}$ 7.6. Greenhouse temperature and relative humidity were $25 \pm 3{ }^{\circ} \mathrm{C}$ and 55 $\pm 3 \%$, respectively, during the growing season. Pots were placed in a glasshouse and irrigated regularly until four true leaves (two cotyledons + four leaves) appeared and were fully grown. Treatments were then carried out ( $24 \mathrm{~d}$ after sowing, DAS).

Two different experiments were conducted to evaluate the effect of water deficiency on Fe and $\mathrm{Zn}$ uptake by German chamomile. In Experiment 1, treatments were arranged in four irrigation regimes (i.e., 95\%, 80\%, $65 \%$, and $50 \%$ field capacity determined gravimetrically) based on a randomized complete block design with five replicates (10 plants per replicate). The plant watering interval was calculated daily. Pots for each treatment were weighed to refill water in order to reach the required moisture level in the pots at their respective stress levels. Irrigation regimes lasted $100 \mathrm{~d}$.

In Experiment 2, irrigation disruptions were applied during five different growth stages of German chamomile based on a randomized complete block design with four replicates (10 plants per replicate). Irrigation treatments consisted in no irrigation during stem formation (43 DAS), flower onset (65 DAS), full bloom (72 DAS), first harvest (76 DAS), and second harvest (90 DAS) as compared with a fully-irrigated control based on the phenology of Matricaria chamomilla L. (Pirzad et al., 2010). During the rest of the season, plants were irrigated at $100 \%$ field capacity (FC) the same as the control plants when soil moisture content decreased to $80 \%$ FC.

Fully expanded leaves were harvested and air-dried at $85{ }^{\circ} \mathrm{C}$ to determine $\mathrm{Fe}$ and $\mathrm{Zn}$. One gram of dried and finely ground plant material was transferred to a porcelain crucible and combusted in a muffle furnace with an inner volume of $5 \mathrm{~L}$ at $470{ }^{\circ} \mathrm{C}$ for $12 \mathrm{~h}$. After cooling to room temperature, $10 \mathrm{~mL} 4 \mathrm{M} \mathrm{HNO}$ were added to dissolve the remaining ash. Two hours later, $40 \mathrm{~mL}$ of deionisate were added and the samples filtered through MN 614 filter into polyethylene bottles (Schnug and Haneklaus, 1997). Insoluble residues were relatively quantified after ashing by estimating the area of the filter papers covered with soot by the MOCHA image processing system (Rundel, 1992). Both Fe and Zn were analyzed by atomic absorption spectroscopy (AAS) employing atomization in an air/acetylene flame (Schnug, 1982).

Statistical analyses were performed with the MSTATC software. Comparison of means was by Student-Neuman Keul's Test (SNK) at $\mathrm{P}<0.05$.

\section{RESULTS AND DISCUSSION}

In Experiment 1, irrigation regimes have no significant effect on Fe and $\mathrm{Zn}$ uptake by German chamomile (Table 1). Despite the nonsignificant effect, total mean Fe (39.68 $\left.\mathrm{mg} \mathrm{kg}^{-1}\right)$ and $\mathrm{Zn}\left(29.15 \mathrm{mg} \mathrm{kg}^{-1}\right)$ were at high levels in the plants (Grejtovský et al., 2006). It seems that severe stress (excessive water/water deficit) is needed to reduce Fe and Zn uptake by German chamomile (Figure 1). 
Table 1. ANOVA results for the effect of irrigation regimes on $\mathrm{Fe}$ and $\mathrm{Zn}$ uptake in Matricaria chamomilla $\mathbf{L}$.

\begin{tabular}{|c|c|c|c|c|c|c|}
\hline \multirow{2}{*}{$\begin{array}{l}\text { Source } \\
\text { of variation }\end{array}$} & \multicolumn{3}{|c|}{ Experiment 1} & \multicolumn{3}{|c|}{ Experiment 2} \\
\hline & df & $\mathrm{Fe}$ & $\mathrm{Zn}$ & $\mathrm{df}$ & $\mathrm{Fe}$ & $\mathrm{Zn}$ \\
\hline Replicates & 4 & $0.003^{\mathrm{ns}}$ & $0.014^{\mathrm{ns}}$ & 3 & $0.004^{\mathrm{ns}}$ & $0.005 \mathrm{~ns}$ \\
\hline Irrigation regimes & 3 & $0.006^{\mathrm{ns}}$ & $0.003^{\mathrm{ns}}$ & 5 & $0.253^{* *}$ & $0.219^{* * *}$ \\
\hline Error & 12 & 0.009 & 0.012 & 15 & 0.013 & 0.064 \\
\hline $\mathrm{CV}, \%$ & & 13.89 & 17.16 & & 8.79 & 13.95 \\
\hline
\end{tabular}

ns, *,**: non significant and significant at $5 \%$ and $1 \%$ probability levels, respectively. df: degrees of freedom; CV: coefficient of variation.
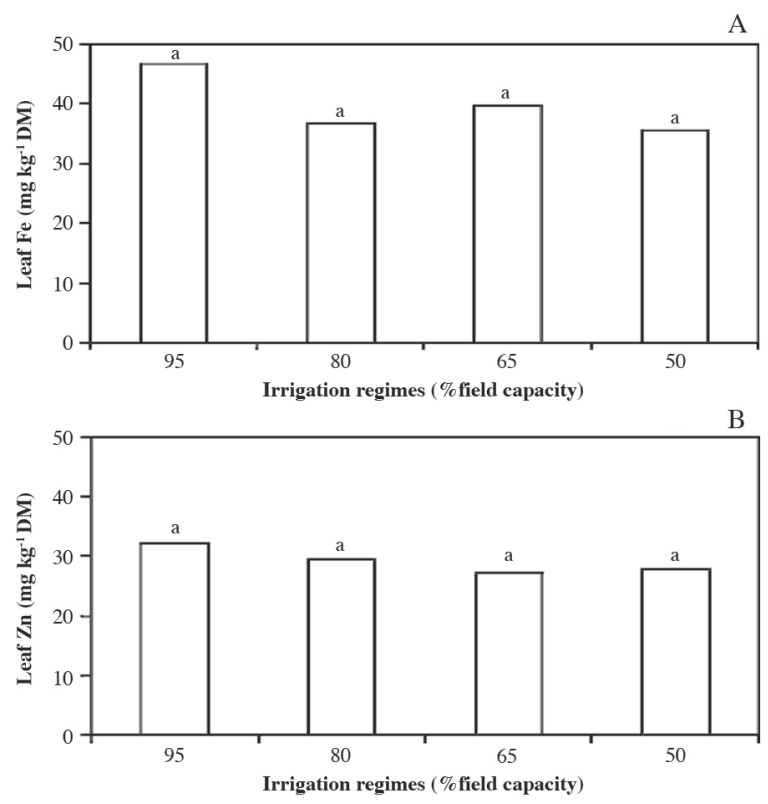

The same letters over the bars indicate non significant differences $(\mathrm{P} \leq 0.05)$.

Figure 1. Comparison of means of $\mathrm{Fe}(\mathrm{A})$ and $\mathrm{Zn}$ (B) uptake under different irrigation regimes in Experiment 1.

In Experiment 2, the effect of irrigation regimes on $\mathrm{Fe}$ and $\mathrm{Zn}$ uptake was highly significant $(\mathrm{P} \leq 0.01)$ (Table 1). Comparisons of means indicated that the highest amount of $\mathrm{Fe}\left(39.0 \mathrm{mg} \mathrm{kg}^{-1}\right)$ was obtained from irrigation disruption at first harvest. This value was similar to $\mathrm{Fe}$ uptake observed in irrigation disruption at flower onset (24.23 $\left.\mathrm{mg} \mathrm{kg}^{-1}\right)$ and full bloom (29.65 mg kg-1). Early and late irrigation disruption significantly reduced Fe uptake. Therefore, irrigation disruption in stem formation (21.3 $\mathrm{mg} \mathrm{kg}^{-1}$ ), second harvest (12.95 $\left.\mathrm{mg} \mathrm{kg}^{-1}\right)$, and the control (7.79 $\mathrm{mg} \mathrm{kg}^{-1}$ ) had a decreasing trend of Fe uptake (Figure 2A). Regression between Fe uptake and irrigation showed a binomial function that had an increasing trend for the latest irrigation disruption for plants with maximum irrigation until the flowering stage. Irrigation continued after the flowering stage and caused reduced Fe uptake by chamomile plants; therefore, the control treatments (irrigation throughout the life cycle) had the lowest Fe uptake (Figure 2A).

Zinc uptake had a maximum value (40.0 mg kg-1) in irrigation disruption at the full boom stage, which is similar to $\mathrm{Zn}$ uptake in irrigation disruption at flower onset (34.75 mg kg-1) and stem formation (32.25 $\mathrm{mg} \mathrm{kg}^{-1}$ ). However, later irrigation disruptions at first and second harvest caused lower $\mathrm{Zn}$ uptake by chamomile. Therefore, the lowest values of $\mathrm{Zn}$ were obtained from irrigation disruption at second harvest $\left(5.0 \mathrm{mg} \mathrm{kg}^{-1}\right)$ and the control (5.5 mg kg-1) (Figure 2B). Regression between $\mathrm{Zn}$ uptake and irrigation was also binomial. This function led to a maximum $\mathrm{Zn}$ uptake in irrigation disruption at full bloom (midway stage of life cycle), and regular irrigation clearly reduced $\mathrm{Zn}$ uptake by chamomile plants (Figure $2 \mathrm{~B}$ ).

$\mathrm{Zn}$ is highly mobile in the soil, is easily taken up by plants, and can thus accumulate in the biomass to extremely high phytotoxic concentrations (Vysloužilová et al., 2003). The accumulation rate depends on soil conditions, plant species, genotype, climate, and agronomic practice (Tlustoš et al., 2001)

According to the observations, the commercial chamomile drug sold in pharmacies contains approximately 20-50 mg Zn kg-1 DM (Grejtovský et al., 2006). Comparable values (30-50 mg kg-1 DM) were reported by Chizzola (1989) in chamomile anthodia samples obtained from growers in Austria. Among the potentially toxic elements usually studied, $\mathrm{Zn}$ belongs to the most mobile trace elements with high bioavailability and high plant transfer. The maximum $\mathrm{Zn}$ concentration in chamomile shoots DM (271.0 mg kg-1) most likely did not reach the phytotoxic level since the plants did not show any signs of chlorosis or any visual symptoms indicating excessive $\mathrm{Zn}$. On the other hand, KabataPendias and Pendias (1992) already assumed potential phytotoxic effects at $\mathrm{Zn}$ concentrations exceeding $100 \mathrm{mg}$ $\mathrm{kg}^{-1}$ plant DM.
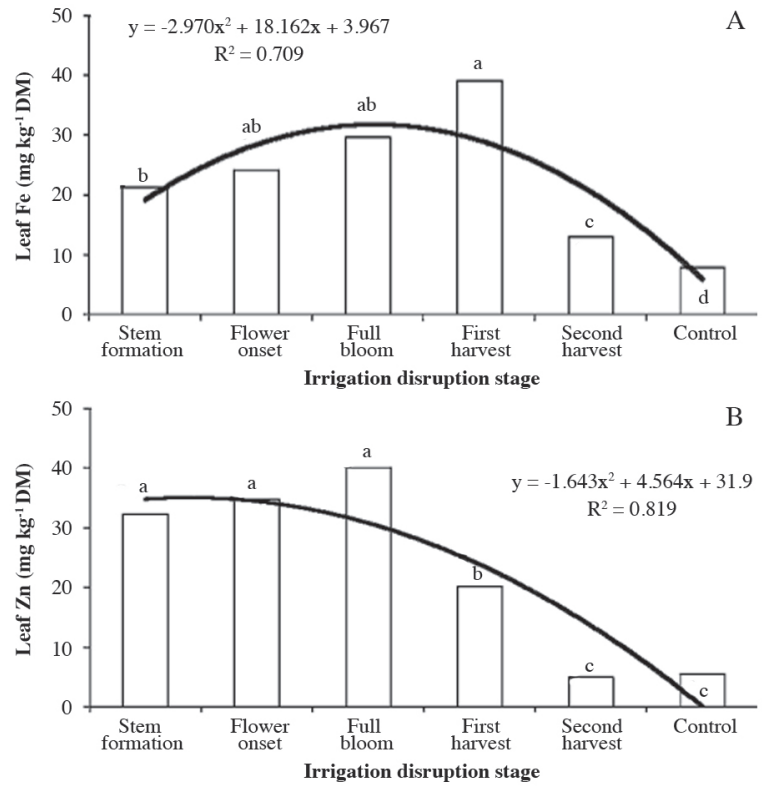

The same letters over the bars indicate non significant differences $(\mathrm{P} \leq 0.05)$.

Figure 2. Comparison of means of $\mathrm{Fe}(\mathrm{A})$ and $\mathrm{Zn}$ (B) uptake of leaves under different irrigation regimes and their regression in Experiment 2. 
Plants take up $\mathrm{Cd}$, which is non-essential and potentially toxic for higher plants, animals, and humans, and it is easily accumulated in edible plant parts. From this point of view, proper attention should be paid to chamomile plants which accumulate Cd (Grejtovský and Pirč, 2000; Grejtovský et al., 2001). Adding Zn to the soil at a rate of $50 \mathrm{mg} \mathrm{kg}^{-1}$ decreased Cd concentration in shoots by $10 \%$ and in anthodia by $37 \%$. An additional increase in soil $\mathrm{Zn}$ concentration caused a decrease in $\mathrm{Cd}$ accumulation in chamomile shoots by $18 \%$ at a rate of $300 \mathrm{mg} \mathrm{Zn} \mathrm{kg}^{-1}$ soil (Grejtovský et al., 2006).

Measurements over longer periods of time did not improve the correlation so that accurate assessment could be done in a relatively short time period (Barton and Abadía, 2006). This fully agrees with our results of $\mathrm{Zn}$ in chamomile plants.

Increasing drainage in low-lying areas can minimize compaction and improve $\mathrm{Fe}$ availability due to both improved oxygen/moisture ratio and general root growth improvement (Tisdale et al., 1993). The opposite effect is less frequently observed with the severity of $\mathrm{Fe}$ chlorosis, although less in the poorly drained soil as compared with normal areas. Possible explanations include reduced water stress in drought conditions, soil salt dilution, and/ or increase in $\mathrm{Fe}$ reduction under anaerobic conditions (Franzen and Richardson, 2000; Hansen et al., 2003). The bioavailability of $\mathrm{Fe}$ increases in soils that are saturated for extended periods. As oxygen is depleted in a saturated soil, $\mathrm{Fe}^{3+}$ is reduced to the most available $\mathrm{Fe}^{2+}$ form for the plant. As the soil dries and the oxygen concentration increases, $\mathrm{Fe}$ is oxidized to the insoluble ferric form. Field crops other than rice have reduced root growth and eventually die under oxygen deprivation in the root zone (El-Shatnawi and Makhadmeh, 2001). Therefore, $\mathrm{Fe}$ chlorosis can be reduced for plants growing in poorly drained soils, but the effect may be negligible or opposite if plant root growth and biochemistry are inhibited by oxygen deficiency.

Although conflicting effects for $\mathrm{Fe}$ nutrition are observed under poorly and well-drained soil conditions, it is generally advisable to implement cultural practices with good water drainage. In addition to drainage, modifying or managing irrigation water can impact the development of Fe deficiency. High carbonate/ bicarbonate concentration in soil water exacerbates $\mathrm{Fe}$ chlorosis (Inskeep and Bloom, 1987; Hansen et al., 2003). Drainage should reduce soil bicarbonate formation in rainfed areas. Under irrigation conditions, acidifying irrigation water reduces bicarbonate concentration and slowly dissolves soil carbonates, which can result in improved $\mathrm{Fe}$ nutrition. Another water management issue is salinity. Accumulation of salts is known to be related to Fe chlorosis. Thus, management of soil salts through proper drainage and irrigation practices can lessen the development of Fe deficiency (Hansen et al., 2003; Siebner-Freibach et al., 2004).

\section{CONCLUSIONS}

In accordance with research objectives, our findings indicated that $\mathrm{Fe}$ and $\mathrm{Zn}$ uptake were not affected by irrigation distances, but they were significantly affected by irrigation regimes as irrigation disruption at different growth stages. Comparisons of means and binomial function between $\mathrm{Fe}$ uptake and irrigation showed an increasing trend for the latest irrigation disruption to flowering stage. However, excess water, irrigation continued after the flowering stage reduced Fe uptake, so that irrigation throughout the life cycle had the lowest Fe uptake. The binomial regression between $\mathrm{Zn}$ uptake and irrigation showed a maximum $\mathrm{Zn}$ uptake in irrigation disruption at full bloom (midway stage of life cycle), and regular irrigation clearly reduced $\mathrm{Zn}$ uptake by chamomile plants. Finally, excess water reduced $\mathrm{Zn}$ uptake, but both excess water and strong water deficit reduced Fe uptake.

Influencia del déficit hídrico en la absorción de hierro y zinc por Matricaria chamomilla $\mathbf{L}$. La deficiencia de hierro y zinc es un factor limitante de la producción con grandes implicaciones para producción de cultivo en terreno en muchas regiones agrícolas del mundo como fuentes esenciales de $\mathrm{Fe}$ y $\mathrm{Zn}$ en dietas para humanos y animales. Para evaluar captación de Fe y $\mathrm{Zn}$ por manzanilla (Matricaria chamomilla $\mathrm{L}$.) cultivada en varias condiciones de sequía, se realizaron dos experimentos bajo condiciones de invernadero. Los tratamientos fueron distribuidos en cuatro regímenes de riego $(95,80,65$, y $50 \%$ capacidad de campo) con cinco replicaciones y seis interrupciones del riego (formación de tallo, inicio de floración, floración completa, primera cosecha, segunda cosecha, y sin interrupción) con cuatro repeticiones basadas en diseño de bloques completos al azar en Experimentos 1 y 2, respectivamente. En Experimento 1, los regímenes de riego no tuvieron efecto significativo en captación de Fe y Zn por la manzanilla alcanzando una media total de Fe $\left(39.68 \mathrm{mg} \mathrm{kg}^{-1}\right)$ y Zn $\left(29.15 \mathrm{mg} \mathrm{kg}^{-1}\right)$. En Experimento 2, la más alta cantidad de Fe $\left(39.0 \mathrm{mg} \mathrm{kg}^{-1}\right)$ se obtuvo de interrupción de riego en primera cosecha, similar a los resultados de interrupción de riego en inicio de floración y floración completa. Pero, la interrupción del riego en formación de tallo $\left(21.3 \mathrm{mg} \mathrm{kg}^{-1}\right)$, segunda cosecha $\left(12.95 \mathrm{mg} \mathrm{kg}^{-1}\right)$ y control $\left(7.79 \mathrm{mg} \mathrm{kg}^{-1}\right)$ tuvo una tendencia a reducir la captación de $\mathrm{Fe}$. El valor máximo de $\mathrm{Zn}\left(40.0 \mathrm{mg} \mathrm{kg}^{-1}\right)$ se obtuvo de interrupción del riego en estado de floración completa, lo cual también fue similar a la interrupción en inicio de floración y formación de tallo. Sin embargo, interrupciones de riego posteriores, en primera y segunda cosechas redujeron la captación de $\mathrm{Zn}$ en manzanilla. Por lo tanto, los menores valores de $\mathrm{Zn}$ se obtuvieron con interrupción de riego en segunda cosecha $\left(5.0 \mathrm{mg} \mathrm{kg}^{-1}\right)$ y control $\left(5.5 \mathrm{mg} \mathrm{kg}^{-1}\right)$. Las regresiones entre captación de $\mathrm{Fe}$ o $\mathrm{Zn}$ y riego mostraron una función binominal. 
Palabras clave: riego, hierro, Matricaria chamomilla, micronutrientes, zinc.

\section{LITERATURE CITED}

Angelova, V., R. Ivanova, V. Delibaltova, and K. Ivanov. 2004. Bioaccumulation and distribution of heavy metals in fiber crops (flax, cotton and hemp). Industrial Crops and Products 19:197205.

Barton, L.L., and J. Abadía. 2006. Iron nutrition in plants and rhizospheric microorganisms. 477 p. Springer, Dordrecth, The Netherlands.

Chai, T.T., N.M. Fadzillah, M. Kusnan, and M. Mahmoodi. 2005. Water stress induced oxidative damage and antioxidant responses in micropropagated banana plantlets. Biologia Plantarum 49:153156.

Chizzola, R. 1989. Metalic trace elements in herbs and spices grown in Austria. Acta Horticulturae 249:89-96.

El-Shatnawi, M.K.J., and I.M. Makhadmeh. 2001. Ecophysiology of the plant-rhizosphere system. Journal of Agronomy and Crop Science 187:1-9.

Fabris, N., and E. Mocchegiani. 1995. Zinc, human diseases and aging. Aging 7(2):77-93.

Franzen, D.W., and J.L. Richardson. 2000. Soil factors affecting Fe chlorosis of soybeans in the Red River Valley of North Dakota and Minnesota. Journal of Plant Nutrition 23:67-78.

Gómez-Galera, S.,A.M. Pelacho, A. Gene, T. Capell, and P. Christou. 2007. The genetic manipulation of medicinal and aromatic plants. Plant Cell Reports 26:1689-1715.

Grejtovský, A., K. Markušová, and A. Eliašová. 2006. The response of chamomile (Matricaria chamomilla L.) plants to soil zinc supply. Plant, Soil and Environment 52:1-7.

Grejtovský, A., and R. Pirč. 2000. Effect of high cadmium concentrations in soil on growth, uptake of nutrients and some heavy metals of Chamomilla recutita (L.) Rauschert. Journal of Applied Botany 74:169-174.

Grejtovský, A., M. Repčák, A. Eliašová, and K. Markušová. 2001. Effect of cadmium on active principle contents of Matricaria recutita L. Herba Polonica 47:203-208.

Haider, S., V. Naithani, J. Barthwal, and P. Kakkar. 2004. Heavy metal content in some therapeutically important medicinal plants. Bulletin of Environmental Contamination and Toxicology 72:119127.

Hansen, N.C., M.A. Schmitt, J.E. Anderson, and J. S. Strock. 2003. Fe deficiency of soybean in the upper Midwest and associated soil properties. Agronomy Journal 95:1595-1601.

Inskeep, W.P., and P.R. Bloom. 1987. Soil chemical factors associated with soybean chlorosis in calciaquolls of western Minnesota. Agronomy Journal 79:779-786.

Institute of Medicine, Food and Nutrition Board. 2001. Dietary reference intakes for vitamin A, vitamin $\mathrm{K}$, arsenic, boron, chromium, copper, iodine, iron, manganese, molybdenum, nickel, silicon, vanadium and zinc. 28 p. National Academy Press, Washington, D.C., USA.

Kabata-Pendias, A., and H. Pendias. 1992. Trace elements in soils and plants. 342 p. $2^{\text {nd }}$ ed. CRC Press, Boca Raton, Florida, USA.

Khan, H.R., G.K. McDonald, and Z. Rengel. 2004 . Zinc fertilization and water stress affects plant water relations, stomatal conductance and osmotic adjustment in chickpea (Cicer arientinum L.) Plant and Soil 267:271-284

Krouma, A., M. Gharsalli, and C. Abdelly. 2003. Differences in response to iron deficiency among some lines of common bean. Journal of Plant Nutrition 26:2295-2305.

Kumar, J., and P.K. Gupta. 2008. Molecular approaches for improvement of medicinal and aromatic plants. Plant Biotechnology Reports 2:93-112.

Molassiotis, A.N., T. Sotiropoulos, G. Tanou, G. Kofidis, G Diamantidis, and I. Therios. 2006. Antioxidant and anatomical responses in shoot culture of the apple rootstock MM 106 treated with $\mathrm{NaCl}, \mathrm{KCl}$, mannitol or sorbitol. Biologia Plantarum 50:6168.

Nable, R.O., and M.J. Webb. 1993. Further evidence that zinc is required throughout the root zone for optimal plant growth and development. Plant and Soil 150:247-253.

Nikam, V.K., and P.D. Chavan. 2009. Influence of water deficit and waterlogging on the mineral status of a medicinal plant Chlorophytum borivilianum. Acta Botanica Hungarica 51(12):105-113

Pirzad, A., M.R. Shakiba, S. Zehtab-Salmasi, A. Mohammadi, R. Darvishzadeh, and A. Hassani. 2010. Phenology of German chamomile and its changes under different irrigation regimes and plant densities. Notulae Scientia Biologicae 2:43-48.

Rundel, R. 1992. Mocha-Image Analysis Software. Jandel Scientific Software, Erkrath, Germany.

Schnug, E. 1982. Untersuchungen zum Einfluss bodenversauernder Duengung auf die Spurennaehrstoff-Versorgung von Kulturpflanzen. PhD thesis. Institut of Plant Nutrition and Soil Science, Kiel University, Kiel, Russia.

Schnug, E., and S. Haneklaus. 1997. Parameters influencing the calcinations of plant materials in muffle furnaces and their importance for micronutrient analysis. p. 667-674. In Hood, T.M., and J. Benton Jones, Jr. (eds.) Soil and plant analysis in sustainable agriculture and environment. Marcel Dekker, New York, USA.

Siebner-Freibach, H., Y. Hadar, and Y. Chen. 2004. Interaction of Fe chelating agents with clay minerals. Soil Science Society of America Journal 68:470-480.

Sivritepe, N., U. Erturk, C. Yerlikaya, I. Turkan, M. Bor, and F. Ozdemir. 2008. Response of the cherry rootstock to water stress induced in vitro. Biologia Plantarum 52:573-576.

Szentmihalyi, K., and M. Then. 2000. Teas of Equiseti herba, Myrtilli folium and Salviae folium. Acta Alimentaria 29:43-49.

Tisdale, S.L., W.L. Nelson, J.D. Beaton, and J.L. Havlin. 1993. Soil fertility and fertilizers. 634 p. $5^{\text {th }}$ ed. Macmillan Publishing, New York, USA.

Tlustoš, P., J. Balík, J. Dvořák, J. Száková, and D. Pavlíková. 2001. Zinc and lead uptake by three crops planted on different soils treated by sewage sludge. Rostlinna Vyroba 47:129-134.

Vysloužilová, M., P. Tlustoš, J. Száková, and D. Pavlíková. 2003. As $\mathrm{Cd}, \mathrm{Pb}$ and $\mathrm{Zn}$ uptake by Salix spp. clones grown in soils enriched by high loads of these elements. Plant Soil and Environment 49:191-196.

Weber, G., and P. Konieczyński. 2003. Speciation of Mg, Mn and $\mathrm{Zn}$ in extracts of medicinal plants. Analytical and Bioanalytical Chemistry 375:1067-1073.

Zimna, D., and R. Piekos. 1988. Extraction of eight essential elements from the leaves of peppermint, Mentha piperita (L.) Huds. Herba Hungarica 27:65-75. 